\title{
Analisis Kesalahan Siswa SMK Dalam Menyelesaikan Soal Kecakapan Matematis Pada Materi Bangun Ruang
}

\author{
Masta Hutajulu1 ${ }^{*}$, Eka Senjayawati², dan Eva Dwi Minarti ${ }^{3}$ \\ $1^{*}, 2,3$ Pendidikan Matematika, IKIP Siliwangi \\ Jalan Terusan Jend. Sudirman, Baros, Kota Cimahi, Jawa Barat, Indonesia \\ 1*masthahutajulu@yahoo.com
}

Artikel diterima: 14-04-2019, direvisi: 14-07-2019, diterbitkan: 30-09-2019

\begin{abstract}
Abstrak
Latar belakang penelitian ini adalah siswa SMK membutuhkan suatu keahlian, kemampuan atau kecakapan untuk mengaplikasikan setiap kompetensi termasuk kecakapan matematis dalam dunia kerja. Kecakapan matematis dinilai sangat penting dan dibutuhkan dalam meningkatkan kualitas dirinya. Tujuan penelitian ini untuk melihat hasil analisis kesalahan siswa SMK dalam menyelesaikan soal kecakapan matematis pada materi bangun ruang. Subyek yang digunakan adalah 5 orang siswa kelas XII di SMK TI Pembangunan Cimahi. Bentuk pengambilan data yaitu pemberian soal tes dengan indikator berbeda pada setiap butir soal. Penelitian ini merupakan sebuah studi pendahuluan. Dari rekapitulasi perhitungan yang telah dilakukan, didapat bahwa persentase kesalahan yang paling banyak dilakukan siswa yakni $80 \%$ pada indikator adaptive reasoning (penalaran adaptif), dimana siswa masih melakukan kesalahan dilihat dari aspek konseptual sebesar 30\%, aspek prosedural juga 30\% serta aspek teknik $20 \%$. Sedangkan persentase kesalahan yang paling sedikit dilakukan siswa yakni $20 \%$ pada indikator procedural fluency (kelancaran prosedural), dimana siswa tidak melakukan kesalahan dilihat dari aspek konseptual, tetapi pada aspek prosedural melakukan kesalahan 10\% serta aspek teknik juga 10\%. Kata Kunci: Analisis Kesalahan, Kecakapan Matematis, Bangun Ruang.

\section{Error Analysis of Vocational High School Students in Resolving Mathematical Proficiency Problems on Three-Dimensional Geometry}

Abstract

The purpose of this study was analyzing the answers of Vocational students on a mathematical proficiency test in three-dimensional geometry. The subjects of this study were 12th-grade students in SMK TI Pembangunan Cimahi. The data obtained from giving a test with indicators of students' mathematical proficiency that is different in each item question. This is a preliminary study. Based on the recapitulation of the results in the analysis and calculations that have been made, it was found that the most percentage of errors made by students is $80 \%$ on adaptive reasoning indicators, where students still make mistakes seen from conceptual aspects by $30 \%$, procedural aspects also $30 \%$ and technical aspects 20\%. While the least percentage of errors is $20 \%$ on procedural fluency indicators, where students do not make mistakes on conceptual aspects, but on procedural aspects and technical aspects make mistakes of $10 \%$.

Keyword: Error Analysis, Mathematical Proficiency, Three-dimensional Geometry.
\end{abstract}


Tujuan pembelajaran matematika Pamungkas, 2018) diantaranya adalah: (1) Menjelaskan keterkaitan antar konsep dan menggunakan konsep maupun algoritma secara luwes, akurat, efisien dan tepat dalam pemecahan masalah; (2) Menggunakan pola sebagai dugaan dalam penyelesaian masalah; (3) Menggunakan penalaran pada sifat, melakukan manipulasi matematika, baik dalam penyederhanaan maupun menganalisa komponen yang ada dalam pemecahan masalah; (4) Mengkomunikasikan gagasan; (5) Melakukan kegiatan motorik, menggunakan pengetahuan matematika; (6) Memiliki sikap menghargai kegunaan matematika dalam kehidupan; (7) Memiliki sikap dan perilaku yang sesuai dengan nilai-nilai dalam matematika dan pembelajarannya.

Groves (2012) mengemukakan sudah banyak negara mengadopsi proses kecakapan matematis sebagai standar kemampuan di sekolah. Hal tersebut berimplikasi bahwa kecakapan matematis bukan sekedar mengembangkan keterampilan dan pemahaman pada siswa saja tetapi proses memahamai, menalar, menggunakan prosedur, memformulasikan, merepresentasi dan menyelesaikan permasalahan, kemampuan untuk berfikir logis, berefleksi, menjelaskan dan membuktikan kebenaran, hingga mempunyai kebiasaan yang produktif, melihat matematika

\section{Pendahuluan} menurut Kemendikbud (Khaerunnisa \&

sebagai hal yang berguna. Pada penelitian Khaerunnisa dan Pamungkas (2018), terdapat efek potensil yang baik hasil belajar siswa yang biasa diberi soal kecakapan matematis.

Groth (2017) mengatakan bahwa siswa sebagai problem solver harus mempunyai kemampuan yang utuh untuk menyelesesaikan setiap masalah. Kenyataan di lapangan pembelajaran matematika masih bersifat tes biasa saja dalam penilaiannya, tidak menggali informasi setiap kompetensi matematis yang kompleks yang mungkin dimiliki oleh siswa. Sebagai contoh kemampuan tersebut dibutuhkan oleh siswa terutama siswa Sekolah Menengah Kejuruan yang cukup banyak berpotensi ke lapangan kerja setelah mereka lulus. Mereka membutuhkan suatu keahlian, kemampuan atau kecakapan untuk mengaplikasikan setiap kompetensi dalam dunia kerja.

Kurikulum 2013 yang tengah berjalan dari beberapa tahun kebelakang ini menuntut matematika sebagai mata pelajaran yang merupakan salah satu sarana belajar dalam pembentukan pola pikir siswa yang diukur dari kemampuan atau kecakapannya. Kecakapan matematis ini dapat membantu siswa dalam memecahkan permasalahan matematik dalam kehidupan sehari-hari. Selain faktor luar seperti peran guru, fasilitas belajar, media pembelajaran, serta model-model pembelajaran yang mendukung terlaksananya proses pembelajaran matematika di kelas, kemampuan personal 
siswa yakni kemampuan atau kecakapan matematis siswa dinilai sangat penting dan dibutuhkan dalam meningkatkan kualitas pembelajaran.

Kecakapan Matematis (mathematical proficiency) menurut Kilpatrick, Swafford, \& Findell (2001) terdiri dari 5 jenis yaitu; (1) conceptual understanding (pemahaman konsep); (2) procedural fluency (kelancaran prosedural); (3) strategic competence (kompetensi strategis),; (4) adaptive reasoning (penalaran adaptif); dan (5) productive disposition (disposisi produktif). Kelima komponen ini tidak bisa dipisahkan karena merupakan satu kesatuan yang saling berkaitan.

Widjajanti (2014) menyatakan pemahaman konseptual merupakan pemahaman terhadap konsep-konsep matematika, siswa dapat mempelajari ide yang baru dengan mengaitkan ide tersebut dengan pengetahuan yang telah dimiliki atau pengetahuan prasyaratnya. Menurut Kilpatrick dkk. (2001), indikator signifikan dari pemahaman konseptual adalah kemampuan untuk menyajikan situasi atematika dengan cara yang berbeda dan mengetahui bagaimana representasi yang berbeda dapat bermanfaat untuk berbagai tujuan. Tingkat pemahaman konseptual siswa berkaitan dengan kekayaan dan luasnya koneksi yang dapat mereka buat.

Dengan memahami konsep matematika secara benar diharapkan siswa mampu menerapkan konsep matematika tersebut pada berbagai situasi. Sebagai contoh sederhana ketika siswa melakukan perhitungan yang melibatkan masalah peluang dan memperoleh nilai perhitungan lebih besar dari 1 , maka siswa yang sudah mempunyai pemahaman konsep benar akan menyimpulkan bahwa hal tersebut tidak tepat. Pemahaman konseptual merupakan kemampuan dasar yang harus dimiliki siswa.

Kelancaran prosedur didefinisikan sebagai keterampilan dan menggunakan prosedur dengan fleksibel, akurat dan efisien. Kompetensi strategis merupakan kemampuan untuk memformulasikan, membuat representasi dan menyelesaikan permasalahan matematika (Widjajanti, 2014). Dengan mempelajari algoritma sebagai suatu prosedur umum, siswa dapat memperoleh pengetahuan bahwa matematika bersifat terstruktur dan dapat menyelesaikan persoalan yang rutin. Kemampuan ini juga merupakan kemahiran dalam menggunakan prosedur secara fleksibel, akurat, efisien, dan tepat. Dengan kemampuan ini, siswa akan dapat menggunakan prosedur atau algoritma yang pernah dipelajari secara tepat, kapan waktu digunakannya dan disesuaikan dengan masalah yang harus diselesaikan.

Kompetensi strategis mengacu pada kemampuan untuk merumuskan, menyajikan, dan menyelesaikan masalah matematika. (Widjajanti, 2014) mengemukakan bahwa karakteristik mendasar yang diperlukan selama proses pemecahan masalah adalah fleksibilitas. Fleksibilitas seseorang dapat berkembang melalui perluasan pengetahuan yang

\section{Mosharafa: Jurnal Pendidikan Matematika}


diperlukan untuk memecahkan masalahmasalah yang tidak rutin.

Kemampuan ini juga merupakan kemahiran atau kemampuan untuk merumuskan, menyajikan, serta memecahkan masalah-masalah matematika. Meskipun di sekolah siswa belajar matematika sering dihadapkan pada masalah yang sama atau mirip dengan menggunakan strategi yang hampir sama dan sudah jelas penyelesaiannya, namun di luar sekolah sering sekali dihadapkan pada situasi yang sulit untuk digambarkan penyelesaian masalahnya. Untuk menyelesaikan masalah seperti ini tentunya siswa harus dapat memformulasikan/merumuskan secara mandiri strategi apa yang dapat digunakan untuk menyelesaikannya.

Penalaran adaptif adalah kemampuan untuk berfikir logis, berefleksi, menjelaskan dan membuktikan kebenaran dan disposisi produktif berkaitan dengan kecenderungan untuk mempunyai kebiasaan yang produktif, melihat matematika sebagai hal yang berguna, memiliki kepercayaan diri dan ketekunan dalam belajar matematika (Widjajanti, 2014). Kemampuan ini juga merupakan kapasitas untuk berpikir logis tentang keterkaitan antara konsep dan situasi, memperkirakan, mereflkesikan, menjelaskan dan menyimpulkan dengan valid/sahih serta pada akhirnya dapat memberikan alasan (justify) dari apa yang dikerjakannya. Pengembangan dari kemampuan ini memerlukan waktu yang cukup panjang, karena siswa perlu waktu untuk menggunakan konsep dan prosedur baru yang diperolehnya dalam beberapa kali untuk dapat menjelaskan dan menjustifikasi melalui pengaitan konsep dan prosedur sehingga mereka memahaminya.

Disposisi produktif berkaitan dengan kecenderungan untuk mempunyai kebiasaan yang produktif, untuk melihat matematika sebagai hal yang masuk akal, berguna, bermakna, dan berharga, serta memiliki kepercayaan diri dan ketekunan dalam belajar matematika. Seperti yang dikemukakan (Widjajanti, 2014) bahwa seorang siswa yang mempunyai disposisi produktif yang tinggi cenderung akan mampu mengembangkan kecakapan matematis mereka dalam hal pemahaman konseptual, kelancaran prosedural, kompetensi strategis, dan penalaran adaptif. Sebaliknya, mereka yang mempunyai kecakapan dalam pemahaman konseptual, kelancaran prosedural, kompetensi strategis, dan penalaran adaptif cenderung akan berkembang disposisi produktifnya. 
Kebiasaan yang cenderung melihat matematika sebagai sesuatu yang masuk akal, berguna, dan berharga bersamaan dengan kepercayaan mereka terhadap ketekunan dan keberhasilan dirinya sendiri dalam matematika. Kemampuan ini akan terpupuk dengan baik jika berhubungan dengan rangkaian kecakapan matematika yang lain. Siswa yang mempunyai banyak pemahaman konsep matematika akan lebih percaya diri dibandingkan dengan mereka yang hanya mempunyai pemahaman konsep yang lebih sedikit. Siswa yang mental matematikanya telah terbangun akan percaya diri terhadap kemampuan yang dimilikinya, mereka melihat bahwa matematika adalah rasional, dapat dimengerti dan terpercaya.

Proses kecakapan dapat menjadi salah satu titik tolak siswa dalam memecahkan masalah. Salah satu bagian dari kecakapan matematis yaitu pemahaman konsep menurut (Hendrayana, 2017) terdapat pengaruh yang langsung pemahaman konsep terhadap pengoperasian konsep mempunyai pengaruh langsung terhadap perelasian konsep. Menurut Amalia, Darhim, \& Priatna (2016), siswa SMK harus memiliki kecakapan dalam melakukan kegiatan matematika untuk mencapai kemampuan memahami masalah, merancang model matematika, menyelesaikan model dan menafsirkan solusi yang diperoleh, yang hal tersebut dinamakan dengan kecakapan matematis.

Dalam hal ini masih banyak siswa melakukan keasalahan dalam mengerjakan soal kecakapan matematis. Untuk Mosharafa: Jurnal Pendidikan Matematika Volume 8, Nomor 3, September 2019

Copyright @ 2019 Mosharafa: Jurnal Pendidikan Matematika menganalisis kesalahan siswa dalam menyelesaikan soal, kita perlu mengklasifikasikan indikator-indikator yanng akan dinilai. Khanifah \& Nusantara (Ruswati, Utami, \& Senjayawati, 2018) mengelompokkan jenis kesalahan siswa sesuai dengan indikator kesalahan dapat dilihat pada tabel 1.

Berdasarkan permasalahan yang di atas, penelitian ini bertujuan menganalisis

Tabel 1.

Jenis Kesalahan Siswa Sesuai dengan Indikator Kesalahan

\begin{tabular}{|c|c|}
\hline $\begin{array}{c}\text { Jenis } \\
\text { Kesalahan }\end{array}$ & Keterangan \\
\hline $\begin{array}{l}\text { Kesalahan } \\
\text { konseptual }\end{array}$ & $\begin{array}{l}\text { (1) Siswa tidak dapat memilih } \\
\text { rumus yang benar atau siswa } \\
\text { lupa terhadap rumus yang } \\
\text { harus digunakan; } \\
\text { (2) Siswa benar dalam memilih } \\
\text { rumus namun tidak dapat } \\
\text { menerapkan rumus tersebut } \\
\text { dengan benar; }\end{array}$ \\
\hline $\begin{array}{l}\text { Kesalahan } \\
\text { prosedural }\end{array}$ & 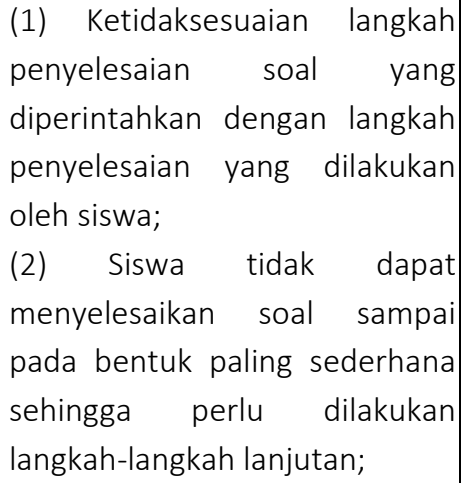 \\
\hline $\begin{array}{l}\text { Kesalahan } \\
\text { teknik }\end{array}$ & $\begin{array}{l}\text { (1) Siswa melakukan kesalahan } \\
\text { dalam menghitung nilai dari } \\
\text { suatu operasi hitung; } \\
\text { (2) Siswa melakukan kesalahan } \\
\text { dalam penulisan yaitu ada } \\
\text { konstanta atau variabel yang } \\
\text { terlewat atau kesalahan } \\
\text { memindahkan konstanta atau } \\
\text { variabel dari satu langkah ke } \\
\text { langkah berikutnya. }\end{array}$ \\
\hline
\end{tabular}


kesalahan siswa SMK dalam mengetahui kemampuan kelancaran menyelesaikan soal kecakapan matematis khususnya pada materi bangun ruang.

\section{Metode}

Penelitian ini merupakan penelitian kualitatif yang bertujuan untuk menganalisis dan mendeskripsikan kesalahan siswa dalam menyelesaikan soal kecakapan matematis (mathematical proficiency). Data yang analisis merupakan jawaban tertulis siswa yang diperoleh dari tes tertulis sampel yang berjumlah 5 orang. Sampel penelitian ini adalah siswa kelas XII SMK TI Pembangunan Cimahi dengan sampel kelas XII yang berjumlah 5 orang. Instrumen tes berupa tes tertulis yang memuat lima butir soal kecakapan matematis (Mathematical Proficiency) dengan materi bangun ruang yang mana pada setiap butir soal memuat kelima indikator kecakapan matematis (Mathematical Proficiency). Hasil perhitungan persentase kesalahan dirumuskan sebagai berikut:

$$
\mathrm{PS}=\frac{J A}{J T} \cdot 100 \%
$$

Keterangan:

PS: Persentase kesalahan tiap indikator tiap butir soal

JA: Jumlah kesalahan yang didapat dari setiap aspek pada setiap butir soal

JT: Jumlah total jawaban siswa pada setiap butir

\section{Hasil dan Pembahasan}

Dari hasil tes tertulis yang diambil dari 5 siswa, penelitian ini bertujuan untuk matematis, maka peneliti memberi 5 soal kepada siswa dimana setiap soal memuat indikator-indikator sebagai berikut:(1) conceptual understanding (pemahaman konsep); (2) procedural fluency (kelancaran prosedural); (3) strategic competence (kompetensi strategis); (4) adaptive reasoning (penalaran adaptif); dan (5) productive disposition (disposisi produktif) (Kilpatrick et al., 2001).

Analisis kesulitan siswa pada setap indikator kelancaran matematis sebagai berikut:

1. Kesulitan siswa pada indikator conceptual understanding (pemahaman konsep).

Berikut adalah respon salah satu siswa terhadap soal nomor 1 (lihat gambar 1 ). Pada soal no 1 dengan indikator conceptual understanding (pemahaman konsep) siswa diharapkan mempunyai pemahaman terhadap konsep-konsep matematika, siswa dapat mempelajari ide yang baru dengan mengaitkan ide tersebut dengan pengetahuan yang telah dimiliki atau pengetahuan prasyaratnya. Dari data hasil nilai siswa pada soal tersebut, siswa yang mampu mengerjakan adalah 3 orang dari 5 orang siswa atau $60 \%$ dan sekitar 2 orang dari 5 orang siswa atau 40\% siswa masih mengalami kesulitan pada indikator conceptual understanding (pemahaman konsep). Hal ini senada dengan penelitian (Yulianingsih \& Dwinata, 2018) yang menyatakan siswa diberikan soal dengan indikator soal yang berbeda-beda hampir seluruh soal terdapat kesalahan konsep

Mosharafa: Jumal Pendidikan Matematika Volume 8, Nomor 3, September 2019 Copyright $\odot 2019$ Mosharafa: Jurnal Pendidikan Matematika 
yang dilakukan siswa. Juga dengan hasil penelitian (Sholihah \& Afriansyah, 2017), yaitu siswa mempunyai pemahaman konsep dan sifat-sifat segiempat yang kurang.

2. Kesulitan siswa pada indikator procedural fluency (kelancaran prosedural).

Berikut adalah respon salah satu siswa terhadap soal nomor 2 (lihat gambar 2). Pada soal no 2 dengan indikator procedural fluency (kelancaran

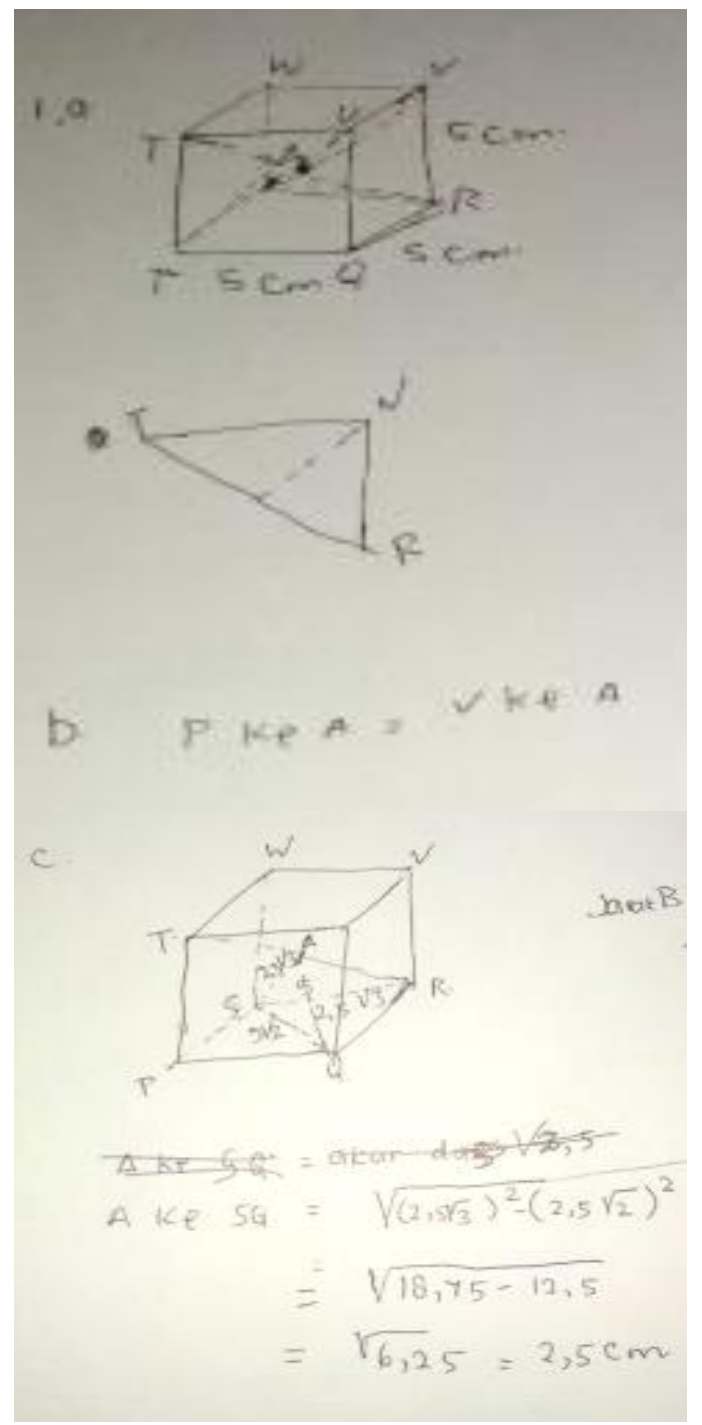

Gambar 1. Respon Siswa Terhadap Soal No. 1 prosedural), siswa dituntut untuk mempunyai keterampilan dan menggunakan prosedur dengan fleksibel, akurat dan efisien. Dari data hasil nilai siswa pada soal no 2 siswa yang mampu mengerjakan 4 dari 5 siswa atau 80\% dan hanya 1 siswa atau 20\% yang masih mengalami kesulitan pada soal no 2 pada indikator pada indikator procedural fluency (kelancaran prosedural). Hal ini senada dengan penelitian (Yani, Roza, Murni, \& Daim, 2019), yang menyatakan siswa mengalami kesulitan dalam memberikan contoh dan bukan contoh dari konsep serta kesulitan dalam mengaitkan berbagai konsep karena tidak memahami konsep dan hanya menghapal rumusnya.

3. Kesulitan pada indikator strategic competence (kompetensi strategis).

Berikut adalah respon salah satu siswa terhadap soal nomor 4 (lihat gambar 3). Pada soal no 4, siswa dituntut mampu untuk memformulasikan, membuat representasi dan menyelesaikan permasalahan matematika. Dari data hasil nilai siswa pada soal no 4 siswa yang mampu mengerjakan adalah 2 dari 5 siswa atau 40\% dan sisanya 3 dari 5 siswa atau $60 \%$ siswa masih mengalami kesulitan pada indikator strategic competence

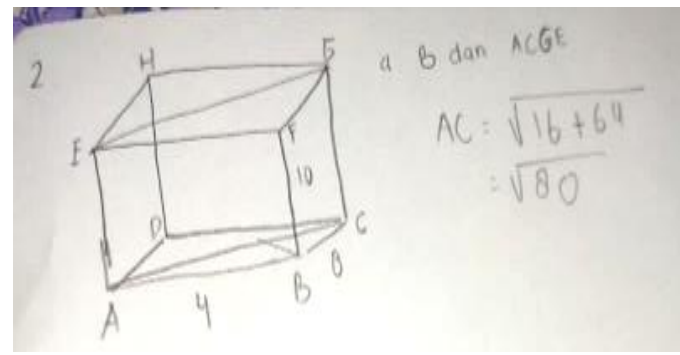

Gambar 2. Respon Siswa Terhadap Soal No. 2 
(kompetensi strategis).

4. Kesulitan pada indikator adaptive reasoning (penalaran adaptif).

Berikut adalah respon salah satu siswa terhadap soal nomor 5 (lihat gambar 4). Pada soal no 5 siswa dituntut mempunyai kemampuan untuk berfikir logis, berefleksi, menjelaskan dan membuktikan kebenaran. Dari data hasil nilai siswa pada soal no 5 dengan indikator menyelesaikan soal-soal aplikasi terlihat siswa yang mampu mengerjakan hanya 1 orang atau 20\% dan 4 siswa atau 80\% siswa masih mengalami kesulitan mengerjakan pada indikator adaptive reasoning (penalaran adaptif). Hal ini disebabkan bahwa pada indikator adaptive reasoning (penalaran

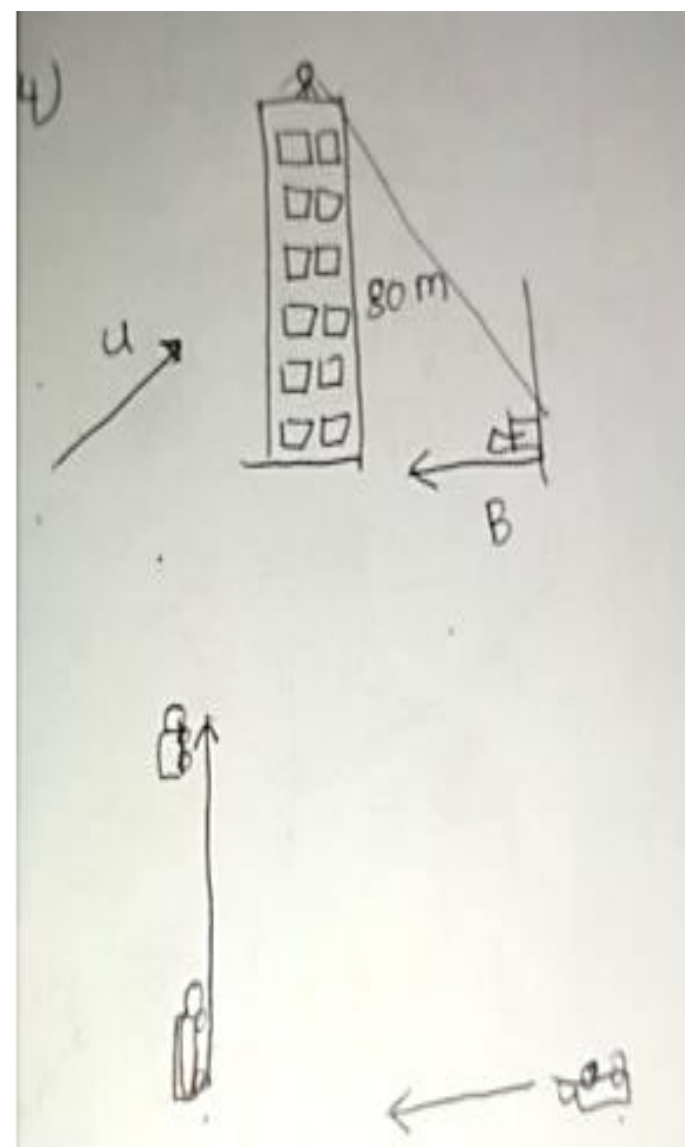

Gambar 3. Respon Siswa Terhadap Soal No. 4 372 adaptif) siswa belum mempunyai kapasitas untuk berpikir logis tentang keterkaitan antara konsep dan situasi, memperkirakan, mereflkesikan, menjelaskan dan menyimpulkan dengan valid/sahih serta pada akhirnya dapat memberikan alasan (justify) dari apa yang dikerjakannya. Dari uraian diatas dapat disimpulkan siswa mengalami kesalahan ketiga jenis kesalahan yaitu kesalahan konseptual, prosedural dan teknik.

5. Kesulitan pada indikator productive disposition (disposisi produktif).

Berikut adalah respon salah satu siswa terhadap soal nomor 3 (lihat gambar 5).

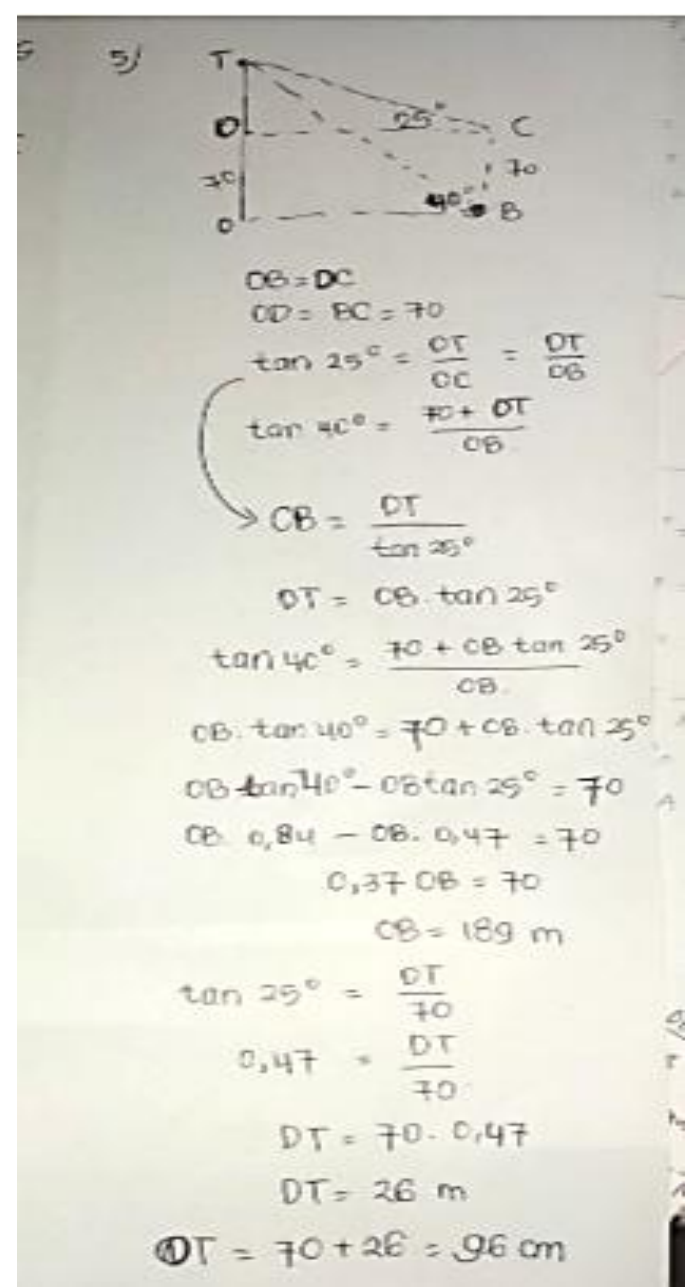

Gambar 4. Respon Siswa Terhadap Soal No. 5

Mosharafa: Jurnal Yendidikan SMatematika Volume 8, Nomor 3, September 2019 Copyright @ 2019 Mosharafa: Jurnal Pendidikan Matematika 


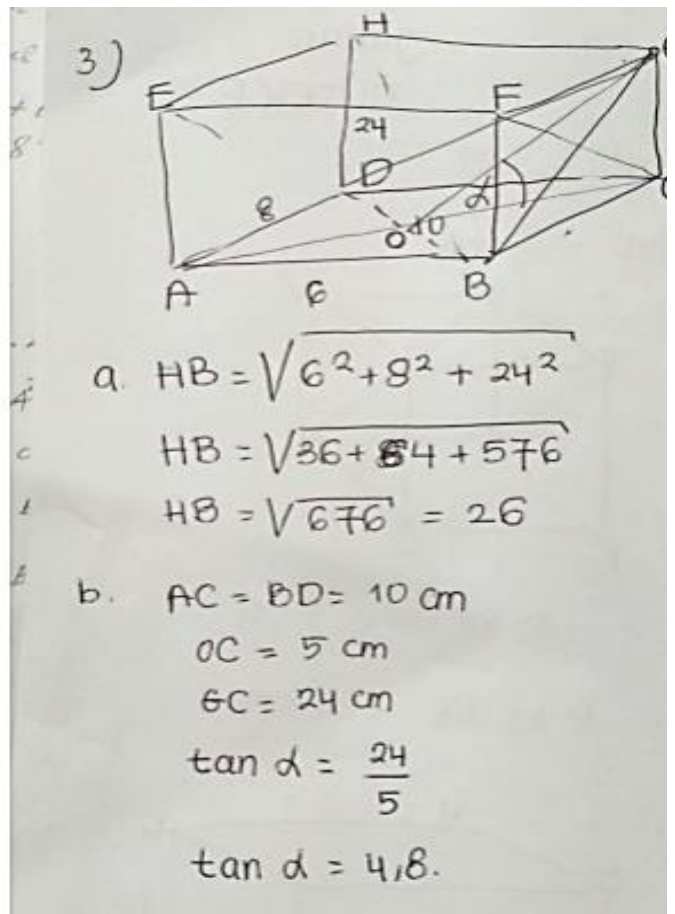

Gambar 5. Respon Siswa Terhadap Soal No. 3

Pada soal nomor 3 tersebut dengan indikator productive disposition (disposisi produktif), siswa berkaitan dengan kecenderungan untuk mempunyai kebiasaan yang produktif, melihat matematika sebagai hal yang berguna, memiliki kepercayaan diri dan ketekunan dalam belajar matematika. hasil penilaian di soal nomor 3 siswa yang dapat mengerjakan soal hanya 2 orang atau 40\% dan 3 orang siswa atau 60\% siswa yang tidak bisa mengerjakan soal pada indikator productive disposition (disposisi produktif).

Hasil rekapitulasi persentase jenis kesalahan pada masing-masing indikator dalam setiap butir soal pada tabel 2 berikut.

Soal kemampuan kelancaran matematis yang diberikan kepada siswa, dirasakan sulit mengerjakannnya oleh siswa. Pada indikator Conceptual understanding
Tabel 2.

Persentase Kesalahan dalam Tiga Aspek pada Setiap Butir Soal

\begin{tabular}{|c|c|c|c|}
\hline No. & $\begin{array}{l}\text { Indikat } \\
\text { or Soal }\end{array}$ & Aspek kesalahan & $\%$ \\
\hline \multirow{3}{*}{1.} & \multirow{3}{*}{$\begin{array}{l}\text { Concep } \\
\text { tual } \\
\text { underst } \\
\text { anding }\end{array}$} & Konseptual & 0 \\
\hline & & $\begin{array}{l}\text { Prosedural } \\
\text { (Ketidaksesuaian langkah } \\
\text { penyelesaian soal yang } \\
\text { diperintahkan) }\end{array}$ & 20 \\
\hline & & $\begin{array}{lr}\text { Teknik (Siswa melakukan } \\
\text { kesalahan } & \text { dalam } \\
\text { menghitung) } & \end{array}$ & 20 \\
\hline \multirow{3}{*}{2.} & \multirow{3}{*}{$\begin{array}{l}\text { Proced } \\
\text { ural } \\
\text { fluency }\end{array}$} & Konseptual & 0 \\
\hline & & $\begin{array}{l}\text { Prosedural (Siswa tidak } \\
\text { dapat menyelesaikan soal } \\
\text { sampai pada bentuk } \\
\text { paling sederhana) }\end{array}$ & 10 \\
\hline & & $\begin{array}{lr}\text { Teknik (Siswa melakukan } \\
\text { kesalahan } \\
\text { penulisan) }\end{array}$ & 10 \\
\hline \multirow{3}{*}{3.} & \multirow{3}{*}{$\begin{array}{l}\text { Strateg } \\
\text { ic } \\
\text { compet } \\
\text { ence }\end{array}$} & $\begin{array}{l}\text { Konseptual (Siswa tidak } \\
\text { dapat memilih rumus } \\
\text { yang benar) }\end{array}$ & 20 \\
\hline & & $\begin{array}{l}\text { Prosedural } \\
\text { (Ketidaksesuaian langkah } \\
\text { penyelesaian soal yang } \\
\text { diperintahkan) }\end{array}$ & 20 \\
\hline & & $\begin{array}{lr}\text { Teknik (Siswa melakukan } \\
\text { kesalahan } & \text { dalam } \\
\text { menghitung) } & \\
\end{array}$ & 20 \\
\hline \multirow{3}{*}{4.} & \multirow{3}{*}{$\begin{array}{l}\text { Adapti } \\
\text { ve } \\
\text { reasoni } \\
\text { ng }\end{array}$} & $\begin{array}{lr}\text { Konseptual (Siswa benar } \\
\text { memilih rumus namun } \\
\text { tidak } \\
\text { menerapkannya) }\end{array}$ & 30 \\
\hline & & $\begin{array}{l}\text { Prosedural (Siswa tidak } \\
\text { dapat menyelesaikan soal } \\
\text { sampai pada bentuk } \\
\text { paling sederhana) }\end{array}$ & 30 \\
\hline & & $\begin{array}{l}\text { Teknik (Siswa melakukan } \\
\text { kesalahan memindahkan } \\
\text { konstanta atau variabel) }\end{array}$ & 20 \\
\hline \multirow{3}{*}{5.} & \multirow{3}{*}{$\begin{array}{l}\text { Produc } \\
\text { tive } \\
\text { disposi } \\
\text { tion }\end{array}$} & $\begin{array}{l}\text { Konseptual (Siswa tidak } \\
\text { dapat memilih rumus } \\
\text { yang benar) }\end{array}$ & 20 \\
\hline & & $\begin{array}{l}\text { Prosedural (Siswa tidak } \\
\text { dapat menyelesaikan soal } \\
\text { sampai pada bentuk } \\
\text { paling sederhana) }\end{array}$ & 20 \\
\hline & & $\begin{array}{lr}\text { Teknik (Siswa melakukan } \\
\text { kesalahan } & \text { dalam } \\
\text { menghitung) } & \end{array}$ & 20 \\
\hline
\end{tabular}


(pemahaman konsep) setelah dianalisis jawaban siswa yang mampu menjawab terbilang cukup baik, karena 3 dari 5 siswa yang mampu menjawab soal pada indikator ini, sehingga dapat dikatakan bahwa kemampuan siswa untuk memberikan alasan tergolong sedang.

Pada indikator procedural fluency (kelancaran prosedural), setelah dianalisis jawaban siswa yang mampu menjawab terbilang baik, 4 dari 5 siswa mampu menggunakan prosedur dengan fleksibel, akurat dan efisien. Hal ini senada dengan penelitian (Asmara, 2016) dan (Irawan, 2018) mengatakan bahwa setiap komponen (strands) kecakapan matematis terkategorikan baik.

Selanjutnya pada indikator strategic competence (kompetensi strategis), setelah dianalisis jawaban siswa yang mampu menjawab terbilang buruk. Terlihat dari jawaban siswa yang tidak fokus kepada pertanyaan dan jawaban. Siswa tidak bisa menganalisis pertanyaan yang diajukan sehingga jawaban yang dibuat siswa seadanya. Hal ini senada dengan hasil penelitian (Dhlamini \& Luneta, 2016) mengatakan bahwa level siswa SMA kelas XII pada materi matriks terkategorikan kurang.

Begitu juga pada indikator Adaptive reasoning (penalaran adaptif), setelah dianalisis jawaban siswa yang mampu menjawab terbilang sangat buruk, karena terlihat dari data siswa sebagian besar siswa tidak mampu untuk memformulasikan, membuat representasi dan menyelesaikan permasalahan matematika.

Selanjutnya indikator Productive disposition (Disposisi produktif), setelah dianalisis jawaban siswa yang mampu menjawab terbilang buruk, 4 dari 5 siswa belum mampu melihat matematika sebagai hal yang berguna, memiliki kepercayaan diri dan ketekunan dalam belajar matematika. Hasil penelitan diperoleh, kecakapan matematis siswa SMK terbilang kurang. Hal ini berbeda dengan penelitian (Yulian, 2018), kecakapan matematis siswa SMP di Bandung utara termasuk kategori baik. Begitu juga dengan penelitian (Awofala, 2017) menyatakan kemampuan kecakapan matematis siswa SMP di Nigeria dengan melihat gender dan performa, terkategorikan baik juga.

Perbedaan hasil yang diperoleh dengan dua penelitian di atas salah satu faktor yang mempengaruhinya adalah subyek penelitian. Dimana karakteristik siswa SMP berbeda dengan karakteristik siswa SMK. Salah satu faktor yang menyebabkan siswa keliru dalam menyelesaikan soal kemampuan kecakapan matematis adalah kurang telitinya siswa dalam proses pengerjaan soal. Hal ini senada dengan penelitian (Gais \& Afriansyah, 2017), faktor kekeliruan berupa kurangnya pemahaman siswa terhadap soal, ketidak lengkapan dalam membaca soal.

\section{Penutup}

Untuk mengatasi rendahnya kemampuan kecakapan matematis siswa, 
dalam menyampaikan konsep sebaiknya guru menggunakan alat peraga dalam menyampaikan materi bangun ruang, sehingga siswa mempunyai pemahaman konsep yang mengakar sehingga tidak gampang lupa konsep yang diajarkan. Selanjutnya memberikan latihan soal-soal tentang mengaitkan berbagai konsep, serta dengan menerapkan model pembelajaran yang dapat mengasah kemampuan kecakapan matematis siswa.

\section{UCAPAN TERIMA KASIH}

Terima kasih peneliti ucapkan kepada Rektor dan Wakil Rektor IKIP Siliwangi yang memberikan dukungan moril dan material serta rekan-rekan dosen Prodi Matematika IKIP Siliwangi yang telah memberikan banyak masukan dan kontribusi terhadap penulisan artikel ini.

\section{DAfTAR PUStaka}

Amalia, K., Darhim, D., \& Priatna, B. . (2016). Peningkatan kompetensi strategis matematis siswa sekolah menengah kejuruan (smk) melalui strategi team-based learning, 5(1). 114.

Asmara, A. S. (2016). Peningkatan kemampuan pemecahan masalah dan disposisi matematis siswa smk dengan pembelajaran berbasis masalah berbantuan multimedia interactive. Jurnal Sekolah Dasar, 1(1).

Awofala, A. O. (2017). Assessing Senior Secondary School Students' Mathematical Proficiency as Related to Gender and Performance in Mathematics in Nigeria. International
Journal of Research in Education and Science, 3(2). 488-502.

Dhlamini, Z. B., \& Luneta, K. (2016). Exploration of the Levels of Mathematical Proficiency Displayed by Grade 12 Learners in Responses to Matric Examinations. International Journal of Educational Sciences, 13(2). 231-246. https://doi.org/https://doi.org/10.39 29/ethz-b-000238666

Gais, Z., \& Afriansyah, E. A. (2017). Analisis Kemampuan Siswa dalam Menyelesaikan Soal High Order Thinking Ditinjau dari Kemampuan Awal Matematis Siswa. Mosharafa: Jurnal Pendidikan Matematika, 6(2). 251-262.

Groth, R. E. (2017). Classroom data analysis with the five strands of mathematical proficiency. The Clearing House: A Journal of Educational Strategies, Issues and Ideas, 90(3). 103-109.

Groves, S. (2012). Developing Mathematical Proficiency. Journal of Science and Mathematics Education in Southeast Asia, 35(2). 119-145.

Hendrayana, A. (2017). Pengaruh Pembelajaran Pendekatan Rigorous Mathematical Thinking ( RMT ) terhadap Pemahaman Konseptual Matematis Siswa SMP. Jurnal Riset Pendidikan Matematika, 4(2). 186199.

Irawan, B, P. (2018). Kecakapan Matematis (Mathematical Proficiency) Siswa dalam Pembelajaran Open-Ended di Sekolah Menengah Pertama. Jurnal Perspektif Pendidikan., 12(1). 60-71. https://doi.org/10.1590/s180998232013000400007

Khaerunnisa, E., \& Pamungkas, A. S. 
(2018). Pengembangan Instrumen Kecakapan Matematis dalam Konteks Kearifan Lokal Budaya Banten pada Materi Bangun Ruang Sisi Datar. Jurnal Matematika Kreatif-Inovatif (Kreano), 9(1). 17-27.

Kilpatrick, J., Swafford, J., \& Findell, B. (Eds.). (2001). Adding it up: Helping children learn mathematics. Washington DC: National Academy Press.

Ruswati, D., Utami, W. T., \& Senjayawati, E. (2018). Analisis Kesalahan Siswa SMP dalam Menyelesaikan Soal Kemampuan Pemecahan Masalah Matematis Ditinjau dari Tiga Aspek. Jurnal MAJU, 5(1). 91-107. https://doi.org/10.1590/s180998232013000400007

Sholihah, S. Z., \& Afriansyah, E. A. (2017). Analisis kesulitan siswa dalam proses pemecahan masalah geometri berdasarkan tahapan berpikir Van Hiele. Mosharafa: Jurnal Pendidikan Matematika, 6(2). 287-298.

Widjajanti, D. B. (2014). Mengembangkan Kecakapan Matematis Mahasiswa Calon Guru Matematika Melalui Strategi Perkuliahan Kolaboratif Berbasis Masalah. UNY.

Yani, C. F., Roza, Y., Murni, A., \& Daim, Z. (2019). Analisis Kemampuan Pemahaman Matematis Siswa pada Materi Bangun Ruang Sisi Lengkung. Mosharafa: Jurnal Pendidikan Matematika, 8(2). 203-214.

Yulian, V. N. (2018). Analysing categories of mathematical proficiency based on Kilpatrick opinion in junior high school. In Journal of Physics: Conference Series (Vol. 1132, p. 012052)). IOP Publishing. https://doi.org/10.1590/s1809-

\section{7}

Yulianingsih, A., \& Dwinata, A. (2018). Analisis Kesalahan Konsep Pecahan pada Siswa Kelas VII A SMP Negeri 13 Satu Atap Tanjungpinang. Mosharafa: Jurnal Pendidikan Matematika, 7(2). 199-206.

\section{Riwayat Hidup PENULIS}

Masta Hutajulu, S.Si., M.Pd.

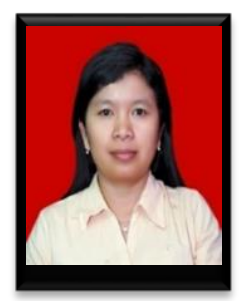

Dosen pendidikan matematika di IKIP Siliwangi, Cimahi. Studi S1 Matematika Universitas Pendidikan Indonesia lulus tahun 2003; S2 Pendidikan Matematika Universitas Pendidikan Indonesia lulus tahun 2010; dan sedang menempuh pendidikan S3 jurusan Pendidikan Matematika Universitas Pendidikan Indonesia, masuk tahun 2016 sampai sekarang.

Eka Senjayawati, S.Pd. M.Pd.

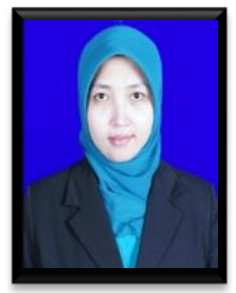

Dosen Tetap di Institut Keguruan dan Ilmu Pendidikan (IKIP Siliwangi) Bandung. Studi S1 Pendidikan Matematika STKIP Siliwangi Bandung lulus tahun 2010; S2 Pendidikan Matematika STKIP Siliwangi Bandung

lulus tahun 2014.

Eva Dwi Minarti, S.Pd. M.Pd.

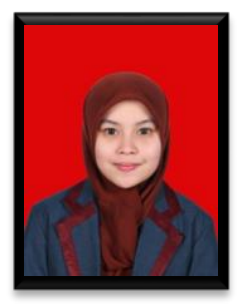

Dosen pendidikan matematika di IKIP Siliwangi, Cimahi. Studi S1 Pendidikan Matematika Universitas Pasundan lulus tahun 2009; S2 Pendidikan Matematika Universitas Pendidikan Indonesia lulus tahun 2012; dan menempuh pendidikan jurusan S3 Pendidikan Matematika Universitas Pendidikan Indonesia, masuk tahun 2016 sampai sekarang. 